\title{
Clustering of Gephyrin at GABAergic but Not Glutamatergic Synapses in Cultured Rat Hippocampal Neurons
}

\author{
Ann Marie Craig,, Gary Banker, ${ }^{2}$ Weiru Chang, ${ }^{1}$ Maureen E. McGrath, ${ }^{1}$ and Anna S. Serpinskaya ${ }^{1}$ \\ 1 Department of Cell and Structural Biology, University of Illinois, Urbana, Illinois 61801, and 2Department of \\ Neuroscience, University of Virginia, Charlottesville, Virginia 22903
}

The molecular mechanisms underlying the establishment of a postsynaptic receptor mosaic on CNS neurons are poorly understood. One protein thought to be involved is gephyrin, a peripheral membrane protein that binds to the inhibitory glycine receptor and functions in clustering this receptor at synapses in cultured rat spinal cord neurons. We investigated the possible association of gephyrin with synapses in cultured rat hippocampal neurons, where glutamate and GABA but not glycine are the principal transmitters. Gephyrin immunoreactivity was detected in axons as well as dendrites, changing from a predominantly axonal to a more dendritic distribution with time in culture. Gephyrin staining was not distributed uniformly, but always took the form of clusters. Small clusters of gephyrin $(0.2$ $\mu \mathrm{m}^{2}$ ), present throughout development, were distributed widely and not restricted to synaptic sites. Larger clusters of gephyrin
(0.4-10.0 $\mu \mathrm{m}^{2}$, sometimes composed of groups of small clusters), which developed in older cells, were localized to a subset of contacts between axons and dendrites. These large clusters were not present at glutamatergic synapses (marked by immunostaining for GluR1), but were closely associated with GABAergic synapses (marked by immunostaining for GABA and glutamic acid decarboxylase). These results, together with previous findings, suggest that gephyrin may function to anchor GABA and glycine receptors, but not glutamate receptors, at postsynaptic sites on central neurons. They also raise the possibility that gephyrin has additional functions, independent of its role at synapses.

Key words: synaptogenesis; receptor clustering; gephyrin; GABA receptor; glutamate receptor; hippocampal neuron; postsynaptic site
Synaptic function depends not only on controlled release of neurotransmitter but also on regulation of the number and distribution of receptors in the postsynaptic membrane. At the neuromuscular junction, the primary model for the development of postsynaptic sites, some of the key proteins that regulate the distribution of the acetylcholine receptor have been identified. Agrin and ARIA are two of the trans-synaptic signaling molecules, whereas the $43 \mathrm{~K}$ protein and perhaps the dystroglycan complex function in anchoring the receptor in the postsynaptic membrane (McMahan et al., 1992; Falls et al., 1993; Froehner, 1993b; Hall and Sanes, 1993; Fallon and Hall, 1994; Apel et al., 1995). It has become incrcasingly clear that receptors are also clustered at postsynaptic sites on neurons [for an elegant example, see Triller et al. (1985)]. Furthermore, neuronal receptors can cluster specifically opposite terminals that release the corresponding transmitter (Craig et al., 1994).

The nature of the molecular signals that induce receptor clustering on neurons is not known, but one of the anchoring proteins has been identified and studied intensively by $\mathrm{H}$. Betz and $\mathbf{J}$. Kirsch and colleagues. Gephyrin, a $93 \mathrm{kDa}$ peripheral membrane protein, was isolated originally by virtue of its co-purification with the glycine receptor during affinity chromatography from mam-

Received Nov. 27, 1995; rcvised Feb. 28, 1996; accepted March 1, 1996.

This research was supported by the Lucille P. Markey Charitable Trust and National Institutes of Health Grant NS33184 to A.M.C., National Institutes of Health Grant NS17112 to G.B., and a Howard Hughes Undergraduate Research Fellowship to W.C. We thank Hannelore Asmussen for preparation of cell cultures, Drs. Pietro DeCamilli, Shelley Halpain, and Richard Huganir for gifts of antibodies, and Dr. Anuradha Rao for comments on this manuscript.

Correspondence should be addressed to Ann Marie Craig, Department of Cell and Structural Biology, University of Illinois, 506 Morrill Hall, 505 South Goodwin Avenue, Urbana, IL 61801.

Copyright $\odot 1996$ Society for Neuroscience $\quad 0270-6474 / 96 / 163166-12 \$ 05.00 / 0$ malian spinal cord (Pfeiffer et al., 1982, 1984). Antisense oligonucleotides against gephyrin inhibit glycine receptor clustering on cultured rat spinal cord neurons (Froehner, 1993a; Kirsch et al., 1993b). Gephyrin binds to the glycine receptor $\beta$ subunit and to tubulin and has been postulated to anchor the glycine receptor to the subsynaptic cytoskeleton (Kirsch et al., 1991; Kirsch and Betz, 1995; Meyer et al., 1995).

Gephyrin may also have other functions in addition to its role in anchoring glycine receptors. Although it was once thought that gephyrin immunoreactivity was restricted to glycinergic postsynaptic sites (Triller et al., 1985), this view has subsequently come into question. Gephyrin has been observed postsynaptic to GABA terminals or colocalized with $\mathrm{GABA}_{\mathrm{A}}$ receptor subunits in the rat spinal cord, cerebellum, and retina (Triller et al., 1987; Mitchell et al., 1993; Bohlhalter et al., 1994; Cabot et al., 1995; SassoèPognetto et al., 1995). In all of these regions, both GABA and glycine are primary inhibitory transmitters and can coexist in the same cells and the same terminals (Ottersen et al., 1988; Todd and Sullivan, 1990; Chen and Hillman, 1993; Koontz et al., 1993). Thus, co-utilization of both transmitters at the same bouton may partly explain the presence of gephyrin at GABAergic synapses in these systems, although this explanation seems inadequate to account for the preponderance of GABAergic synapses that contain gephyrin [ $>95 \%$ of GABAergic sympathetic preganglionic neuron inputs as determined by Cabot et al. (1995)]. In addition, gephyrin immunoreactivity in the retinal inner plexiform layer showed a better correspondence with immunoreactivity for the $\mathrm{GABA}_{\mathrm{A}}$ receptor $\alpha 2$ subunit than for glycine receptors (SassoèPognetto et al., 1995). Furthermore, gephyrin is expressed abundantly in regions of the brain that lack the ligand-binding $\alpha$ subunit of the glycine receptor, although these regions do express 

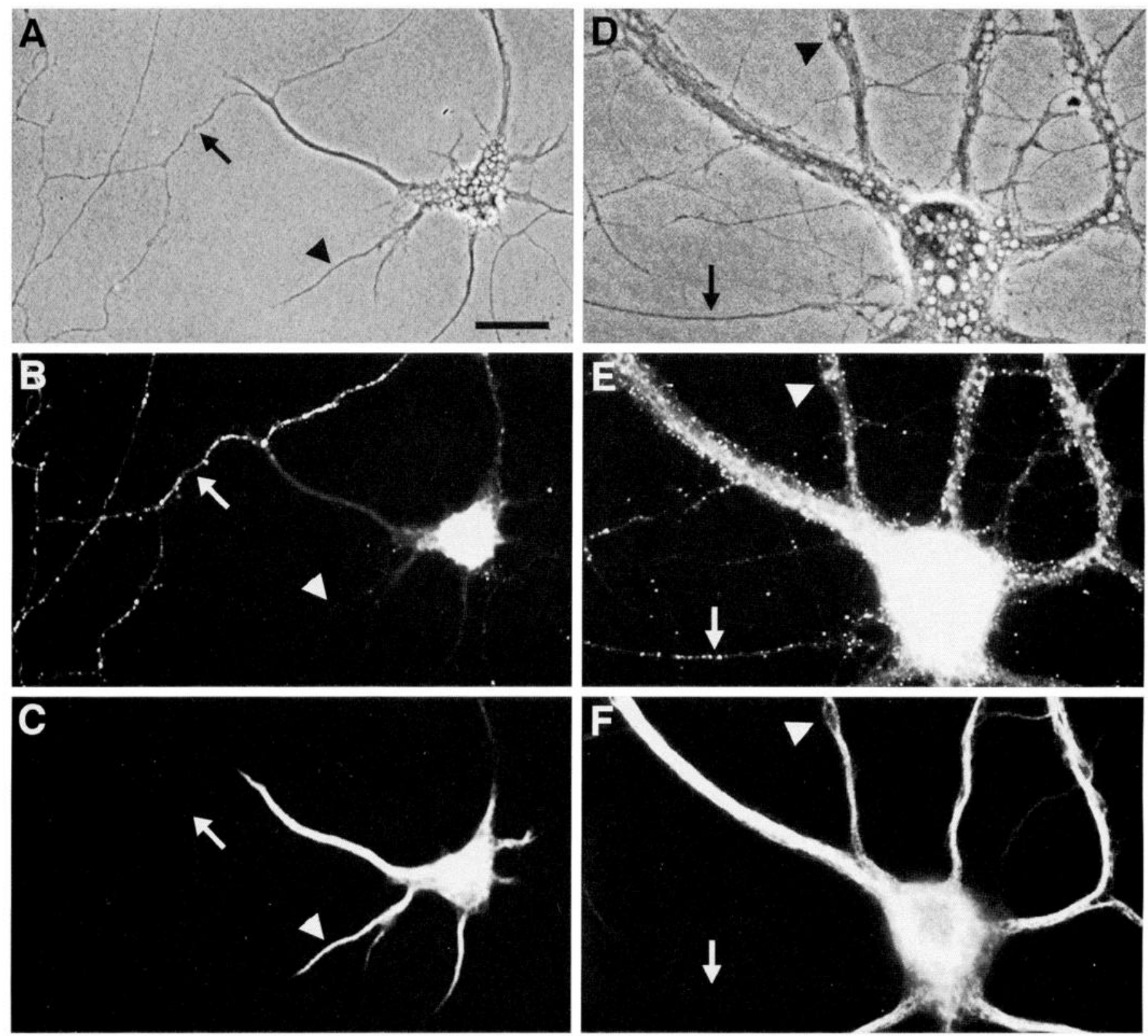

Figure 1. Segregation of gephyrin first to axons and then to dendrites during the development of hippocampal neurons in culture. Neurons were double-labeled for gephyrin $(B, E)$ and the dendritic protein MAP2 $(C, F)$ after $8 \mathrm{~d}(A-C)$ or $22 \mathrm{~d}(D-F)$ in culture. Phase-contrast micrographs $(A, D)$ reveal the increase in complexity of the axonal and dendritic network. In the younger neurons, gephyrin immunoreactivity was strong in axons (arrow) but undetectable in dendrites (arrowhead). In the more mature neurons, gephyrin was restricted mainly to dendrites (arrowhead) but still detectable in dispersed puncta in a small subset of axons (arrow). The presence of gephyrin immunoreactivity in axons was confirmed in additional experiments by double-label immunocytochemistry for neurofilament 200 (data not shown). Gephyrin immunoreactivity was always detected in a punctate pattern. Scale bar (shown in $A$ ): $20 \mu \mathrm{m}$.

the glycine receptor $\beta$ subunit (Malosio et al., 1991; Kirsch and Betz, 1993; Kirsch et al., 1993a). In fact, gephyrin is expressed in many non-neural tissues, including kidney, lung, and liver (Prior et al., 1992). The presence of alternative splice variants at four sites in the N-terminal-half of gephyrin also supports the idea of multiple functions (Prior et al., 1992).

To assess further the possible association of gephyrin with nonglycinergic synapses, we studied its expression and distribution in cultures of rat hippocampal neurons. These cultures are composed primarily of glutamatergic pyramidal cells together with a small number ( $\sim \%)$ of GABAergic interneurons (Goslin and Banker, 1991; Benson et al., 1994). The cultured neurons form structurally and functionally competent synapses and cluster glutamate and GABA receptors at postsynaptic sites opposite terminals releasing the corresponding transmitters (Bartlett and Banker, 1984; Fletcher et al., 1991, 1994; Craig et al., 1993, 1994; Eshhar et al., 1993). GABA is the predominant inhibitory transmitter in the hippocampus, whereas there is no evidence for glycinergic transmission in the hippocampus or in hippocampal cultures. Synaptically activated inhibitory currents in hippocampal cultures are blocked by GABA receptor antagonists (Collingridge et al., 1984; Segal and Barker, 1984; Bekkers and Stevens, 1991). mRNAs encoding the $\alpha 2$ and $\beta$ subunits of the glycine receptor are expressed in the embryonic hippocampus (Malosio et al., 

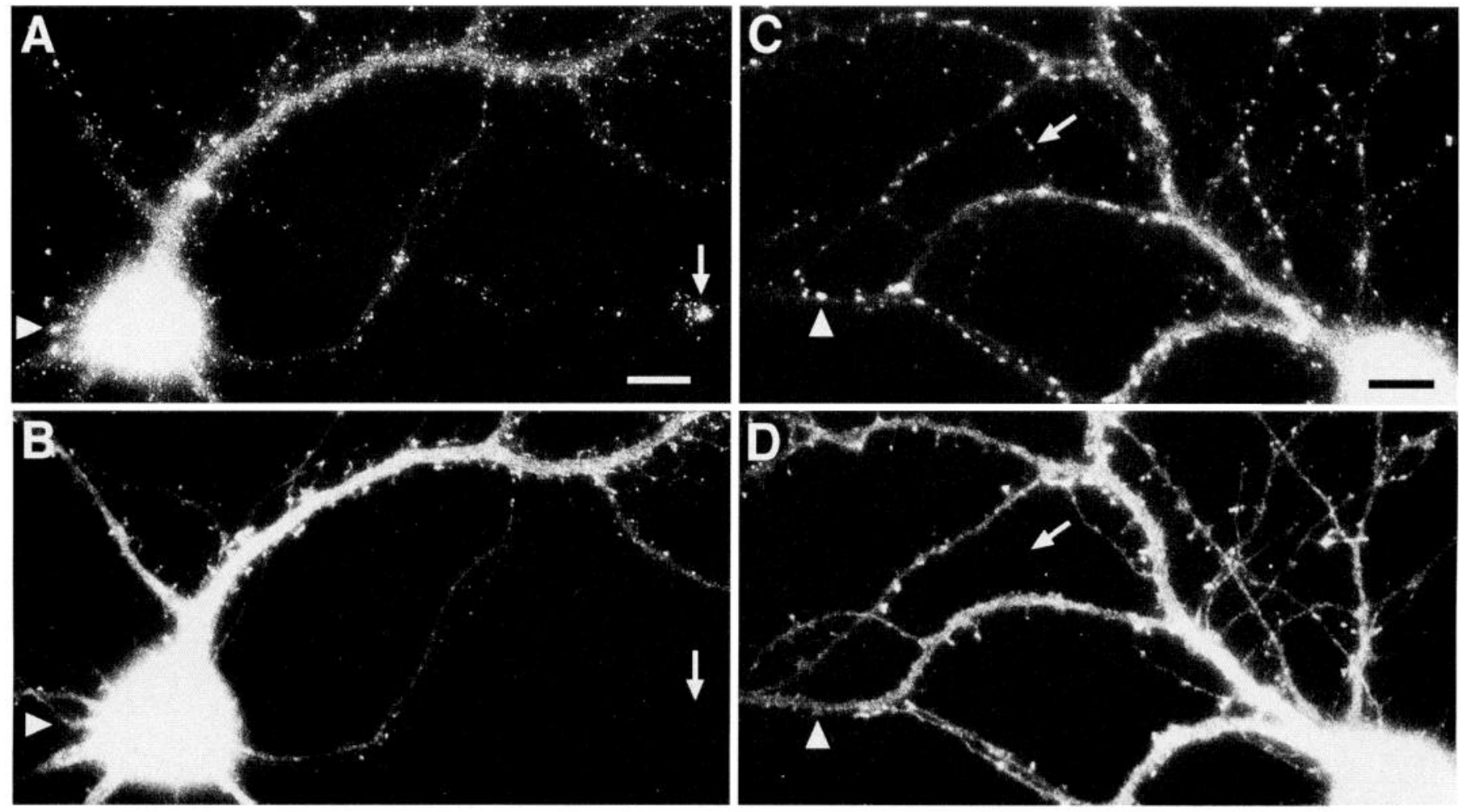

Figure 2. Development of large gephyrin clusters on dendrites. Hippocampal neurons were immunolabeled after $12 \mathrm{~d}(A, B)$ or $16 \mathrm{~d}(C, D)$ in culture for gephyrin $(A, C)$ and the glutamate receptor subunit GluR1 $(B, D)$. GluR1 is segregated to dendrites and has begun to form postsynaptic clusters on spines. At 12 d, gephyrin was present in both axons (arrow) and dendrites. In dendrites, in addition to the small clusters, a few large gephyrin clusters had formed (arrowhead). By $16 \mathrm{~d}$, axonal labeling had decreased but was still detectable in spots (arrow), and the number of large dendritic clusters had increased (arrowhead). Scale bars (shown in $A$ and $C$ ): $10 \mu \mathrm{m}$.

1991), however, and strychnine-sensitive responses to application of glycine can be recorded transiently during hippocampal development (Ito and Cherubini, 1991). Thus, it is quite possible that glycine receptors are present but lack a synaptic function in the hippocampal cultures.

We found that prominent clusters of gephyrin immunoreactivity were associated selectively with GABAergic but not glutamatergic synapses, suggesting a possible role in anchoring GABA receptors as well as glycine receptors. Smaller clusters of gephyrin immunoreactivity were distributed broadly within both axons and dendrites and bore no relationship to synaptic sites. This raises the possibility that gephyrin has additional functions in neurons, unrelated to receptor anchoring.

\section{MATERIALS AND METHODS}

Cell cultures. Hippocampal cultures were prepared as described previously (Banker and Cowan, 1977; Goslin and Banker, 1991). Briefly, hippocampi from 18-d-old rat embryos were dissociated by treatment with trypsin and trituration with a constricted Pasteur pipette. The cells were plated on poly-L-lysine-coated glass coverslips in minimal essential medium (MEM) with $10 \%$ horse serum. Plating densities ranged from 48 to $7200 \mathrm{cells} / \mathrm{cm}^{2}$. After the cells had attached to the substrate, the coverslips were transferred to dishes containing a monolayer of astroglial cells and oriented so that the neurons faced the glia but did not contact them. Cultures were maintained in serum-free MEM with N2 supplements (Bottenstein and Sato, 1979), $0.1 \%$ ovalbumin, and $0.1 \mathrm{~mm}$ pyruvate. Cytosine arabinoside $(5 \mu \mathrm{M})$ was added 2-3 d after plating to inhibit the proliferation of non-neuronal cells.

Antibodies. MAb 7a specific for gephyrin was obtained from Boehringer Mannheim (Indianapolis, IN; now discontinued) and was used at 2-4 $\mu \mathrm{g} / \mathrm{ml}$ (Pfeiffer et al., 1984; Kirsch and Betz, 1993). MAb bd17 against the $\mathrm{GABA}_{\mathrm{A}}$ receptor $\beta 2 / 3$ subunits was also obtained from Boehringer Mannheim and used at 5-10 $\mu \mathrm{g} / \mathrm{ml}$ (Ewert et al., 1990). Rabbit antisera against microtubule-associated protein 2 (MAP2) was a gift of Shelley Halpain, University of Virginia, and was used at a 1:10,000 dilution (Halpain and Greengard, 1990). Rabbit anti-neurofilament 200 antibodies (Sigma, St. Louis, MO) were used at 1:2000. Rabbit antibodies against synaptophysin were provided by Pietro DeCamilli, Yale University, and used at 1:8000 dilution (Navone et al., 1986). Guinea pig antibodies against the glutamate receptor GluR1 were obtained from Richard $\mathrm{Hu}$ ganir, Johns Hopkins University, and used at 1:1000 (crude sera) or 5-10 $\mu \mathrm{g} / \mathrm{ml}$ (affinity-purified antibodies) (Blackstone et al., 1992). GABAergic axons and terminals were identified with rabbit anti-GABA (Sigma; $1: 10,000)$ and rabbit K-2 anti-glutamic acid decarboxylase (anti-GAD) (Chemicon, Temecula, CA; 1:1000; Kaufman et al., 1991). All of these primary antibodies have been well characterized previously by Western blot analysis and immunohistochemistry. Secondary antibodies and avidin conjugates were obtained from Vector Labs (Burlingame, CA) and used at $2-5 \mu \mathrm{g} / \mathrm{ml}$.

Immunocytochemistry. Neurons usually were fixed with $4 \%$ formaldehyde, $4 \%$ sucrose in PBS for $15 \mathrm{~min}$ at $37^{\circ} \mathrm{C}$ and permeabilized with $0.25 \%$ Triton X-100 for $5 \mathrm{~min}$. The addition of $0.1 \%$ glutaraldehyde to the fixative or permeabilization with NP40 instead of Triton X-100 resulted in decreased intensity but no change in the pattern of gephyrin immunoreactivity. Cells were preincubated in $10 \%$ bovine serum albumin (BSA) for $30 \mathrm{~min}$ at $37^{\circ} \mathrm{C}$ and then incubated in primary antibody in $3 \%$ BSA either $2 \mathrm{hr}$ at $37^{\circ} \mathrm{C}$ or overnight at $4^{\circ} \mathrm{C}$. For double-labeling, both primary antibodies were incubated together except for those experiments involving the $\mathrm{K}-2$ anti-GAD. In those experiments, primary antibodies were incubated sequentially: anti-gephyrin, anti-GAD, and then both secondary antibodies. Secondary antibodies were usually combinations of Texas red- or fluorescein isothiocyanate (FITC)-conjugated horse antimouse, goat anti-rabbit, or goat anti-guinea pig IgGs. For greater sensitivity in some experiments, biotinylated secondary antibodies were used in combination with FITC- or Texas red-avidin D. Controls included incubations with no primary antibody and comparisons of double- and single-labeled samples to ensure the independence of labeling in the double-label experiments. Coverslips were mounted in elvanol with $2 \%$ 1,4-diazabicyclo[2,2,2]octane. Cells were photographed with Kodak 

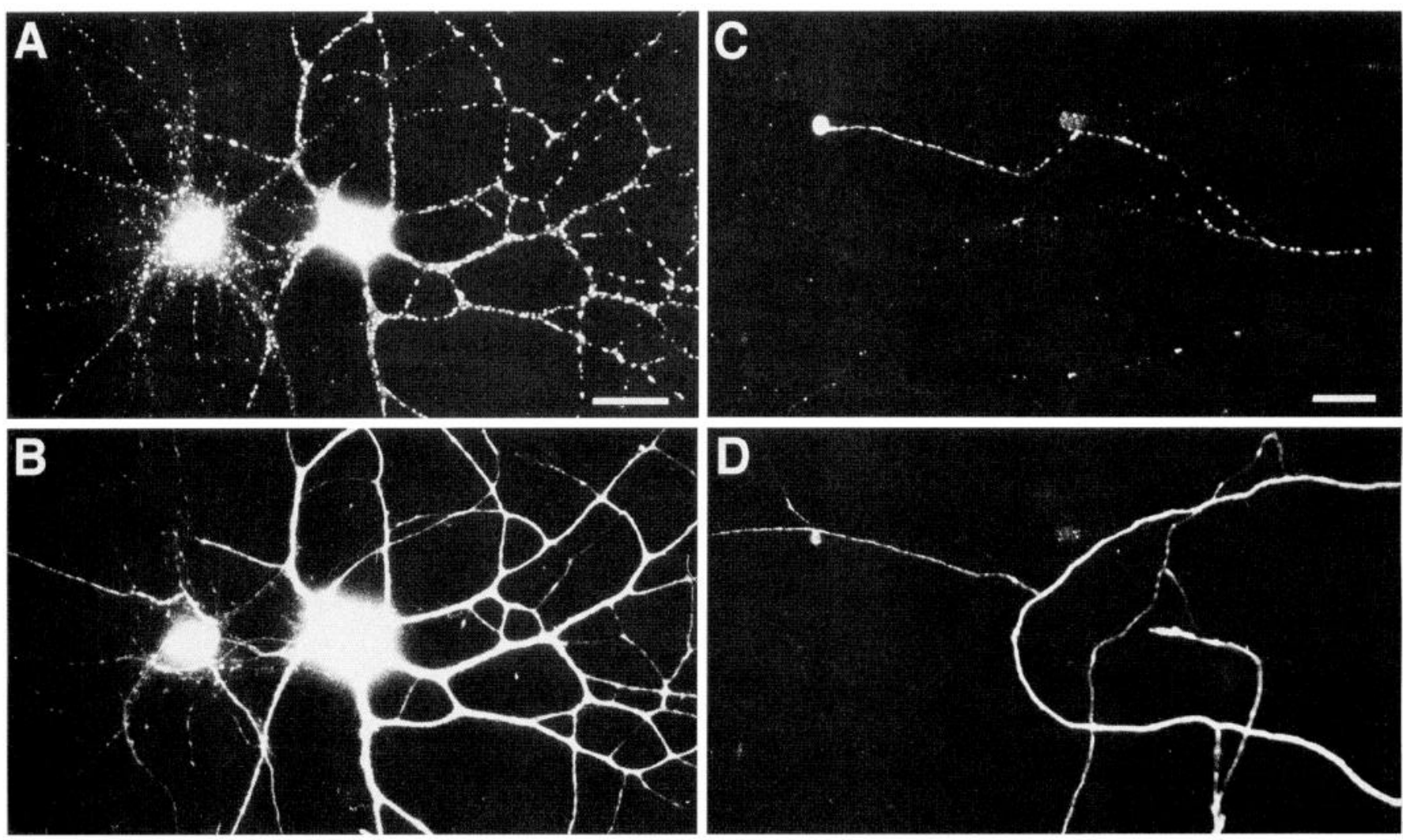

Figure 3. Gephyrin expression by both pyramidal and GABAergic neurons. Hippocampal neurons were immunolabeled after 21-24 d in culture for gephyrin $(A, C)$ and GABA $(B, D)$. Gephyrin immunoreactivity was detected in a punctate dendritic pattern in both pyramidal neurons (cell at left in $A$, $B$ ) and GABAergic interneurons (cell at right in $A, B$ ). The apparent staining of the pyramidal cell soma by GABA is background that is attributable to the greater thickness of the cell body. The fine-staining of processes surrounding the pyramidal cell soma is typical of GABA axon staining. The minority of axons exhibiting gephyrin immunoreactivity in mature cultures $(C)$ generally did not correspond to GABA axons $(D)$. As in the example shown, gephyrin immunoreactivity in axons of older neurons was typically strongest at the tip. Scale bars: $A, B, 30 \mu \mathrm{m} ; C, D, 10 \mu \mathrm{m}$.

TMAX P3200 film through $25-100 \times$ objectives on a Zeiss microscope. Images were prepared for presentation using a Nikon Coolscan scanner, Adobe Photoshop, and Shinko dye sublimation printer. In some cases, images were collected directly with a Photometrics series 250 cooled CCD camera.

Quantitation. For quantitative analysis, digital images were collected with a Photometrics series 250 cooled CCD camera and stored on a Pinnacle rewriteable optical drive. Images were analyzed with IPLab software. After background subtraction of the dark current image, threshold intensity was set for gephyrin images to include for measurements only the clusters, i.e., only pixels above a user-defined intensity. Threshold intensity was chosen manually for each image to include the maximum number of individual clusters with minimal coalescence of clusters in brighter areas. Intensity and area were then measured for each spot above threshold. Raw intensity values were linearly scaled relative to the brightest spot for each image to yield the relative intensity values (see Table 1). A gephyrin image with numbered hot spots was overlaid with the corresponding GABA image, and each gephyrin hot spot was classified as GABA-positive (colocalization) or GABA-negative (no colocalization). Regions immediately surrounding the soma were excluded from analysis because of high background fluorescence from the thickness of the cell body. The results of these measurements were analyzed in Cricketgraph and Microsoft Excel (see Table 1).

\section{RESULTS}

\section{Distribution of gephyrin in axons and dendrites}

Embryonic rat hippocampal neurons in low-density culture were assayed for the expression and localization of gephyrin using the previously characterized monoclonal antibody 7a (Pfeiffer et al., 1984; Kirsch and Betz, 1993). Specificity of the gephyrin antibody was confirmed by Western blot analysis on rat forebrain tissue. As expected, a single strongly immunoreactive band of $93 \mathrm{kDa}$ was obtained (data not shown). In hippocampal cultures, gephyrin immunoreactivity was observed in all neurons at all ages examined, from 2 to $26 \mathrm{~d}$ in culture. Immunoreactivity was not uniformly distributed but was present in a pattern of small puncta.

Surprisingly, in light of previous results (Triller et al., 1985, 1987; Mitchell et al., 1993; Cabot et al., 1995), gephyrin was not restricted to dendrites but was clearly present in axons as well. In fact, in younger neurons (2-10 d in culture), gephyrin was more abundant in axons than in dendrites (Fig. $1 A-C$ ). This distribution changed with development. In older neurons, gephyrin seemed to be more abundant in dendrites than in axons (Fig. 1D-F). Although some of the immunoreactivity associated with dendrites in older cultures may have been attributable to axons coursing along the edges of dendrites, most isolated axons lacked immunoreactivity. Moreover, immunoreactive puncta were present throughout the breadth of dendrites, even in very low-density cultures where dendrites are contacted by few axons.

The transition from a predominantly axonal to a predominantly dendritic localization occurred gradually. At $12 \mathrm{~d}$ in culture (Fig. $2 A, B)$, there was both dendritic and axonal immunoreactivity. Gephyrin was present in sparsely distributed puncta in isolated axons and was particularly abundant near axonal growth cones. Some of the immunoreactive puncta near dendrites were actually outside the boundaries of the dendrites proper and were no doubt attributable to axons coursing parallel to the dendrites. By $16 \mathrm{~d}$ in 

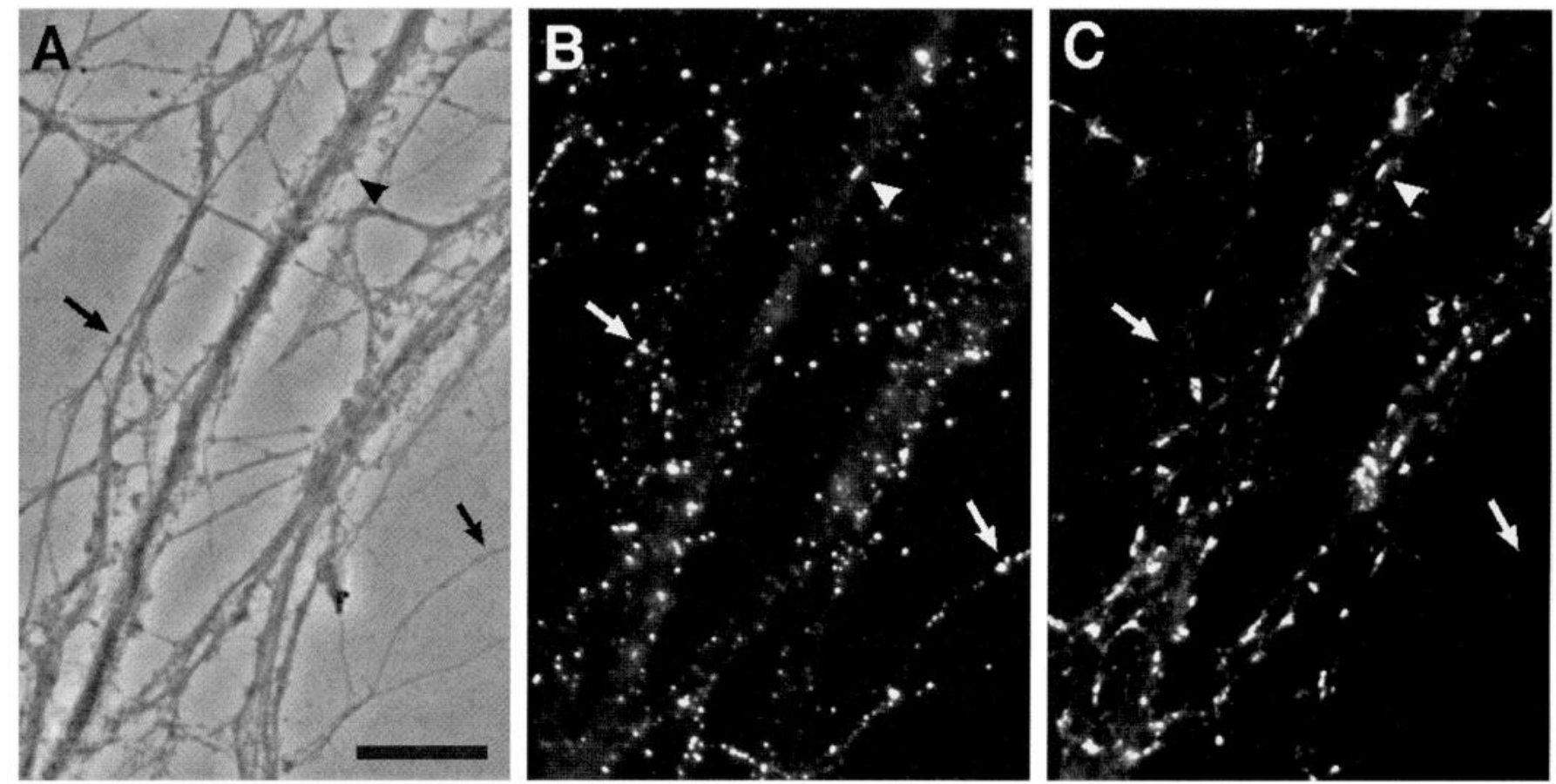

Figure 4. Nonsynaptic localization of small gephyrin clusters. Hippocampal neurons after 2 weeks in culture were immunolabeled for gephyrin $(B)$ and the synaptic vesicle protein synaptophysin $(C)$. Only one elongated gephyrin cluster (arrowhead) exhibited a clear synaptic localization evidenced by colocalization with synaptophysin. The vast majority of the small round gephyrin clusters were present at nonsynaptic sites (arrows), and the vast majority of synaptic vesicle clusters contained no detectable gephyrin. These conclusions were confirmed by superposition of color images (not shown). Scale bar (shown in $A$ ): $10 \mu \mathrm{m}$.

culture (Fig. 2C,D), gephyrin immunoreactivity had nearly disappeared from isolated axons, and immunoreactivity had increased within the boundaries of dendrites. In mature cultures $(>3$ weeks), gephyrin immunoreactivity was present primarily within the boundaries of dendrites (see Figs. 5-9), but a small minority of axons continued to express gephyrin.

As the neurons matured in culture, the distribution of gephyrin changed in another way: larger clusters of gephyrin immunoreactivity appeared. These larger clusters could first be observed in a few cells at 10-12 d in culture (Fig. 2) and were present in most cells by 3 weeks in culture. Gephyrin clusters were present in the somata and dendrites of both the GABAergic interneurons and the non-GABAergic pyramidal cells (Fig. $3 A, B$ ). Because gephyrin was detected in only a minority of mature axons, we wondered whether these might correspond to the axons of GABAergic cells. This proved not to be the case. Although a few gephyrinimmunoreactive GABAergic axons were observed, most of the gephyrin-immunoreactive axons were not GABAergic, and most GABAergic axons lacked detectable gephyrin immunoreactivity (Fig. $3 C, D$ ).

\section{Relationship of gephyrin with synapses}

Are the gephyrin clusters associated with either glutamatergic or GABAergic synapses? This question was addressed by labeling simultaneously for gephyrin and a marker of glutamatergic synapses (GluR1)(Fig. 5), or markers of GABAergic synapses (either GABA itself, GAD, or the $\mathrm{GABA}_{\mathrm{A}}$ receptor $\beta 2 / 3$ subunits) (Figs. $6-9$ ), or the general synaptic marker synaptophysin (Fig. 4). The localization of the small gephyrin clusters bore no relationship to any of the pre- or postsynaptic proteins listed above. Because of the sheer number of clusters in older neurons, there was occasional overlap in staining for gephyrin and synaptophysin as a marker for synaptic vesicles, but the majority of puncta did not overlap (Fig. 4). Similarly, there was no correspondence between the small gephyrin clusters and either GluR1-labeled glutamatergic synapses or GAD-labeled GABAergic synapses (Figs. 5, 8). The small gephyrin clusters seemed to be distributed randomly and were not associated with any clearly discernible morphological feature.

The large gephyrin clusters were observed on dendritic shafts or cell bodies but not on dendritic spines. Thus it seemed unlikely that they would be associated with glutamatergic synapses, which are particularly prominent on dendritic spines (Craig et al., 1993). Double-labeling experiments bore this out (Fig. 5). The large gephyrin clusters did not colocalize with GluR1-labeled synapses but had a distinct, nonoverlapping distribution. The pattern of the large gephyrin clusters was reminiscent of the pattern of $\mathrm{GABA}_{\mathrm{A}}$ receptors (as marked by staining with antibodies that recognize the $\beta 2$ and $\beta 3$ subunits; see Craig et al., 1994). Because the gephyrin and GABA receptor antibodies available were raised in the same species, it was not possible to compare their distributions in the same cells by double-labeling; however, from single-labeling experiments, the patterns of labeling of the two proteins were strikingly similar. Both types of clusters were of approximately the same size, both tended to be elongated in shape, and both were present on dendritic shafts but not on spines (Fig. 6). The only obvious difference between the staining patterns of the $\mathrm{GABA}_{\mathrm{A}}$ receptor subunits and gephyrin in mature cells was that the latter was also present in small clusters.

Double-labeling with GABA revealed that the large gephyrin clusters occurred at sites of contact between dendrites and GABAergic axons (Fig. 7). Although GABA is present along the length of GABAergic axons, the synthetic enzyme GAD is con- 

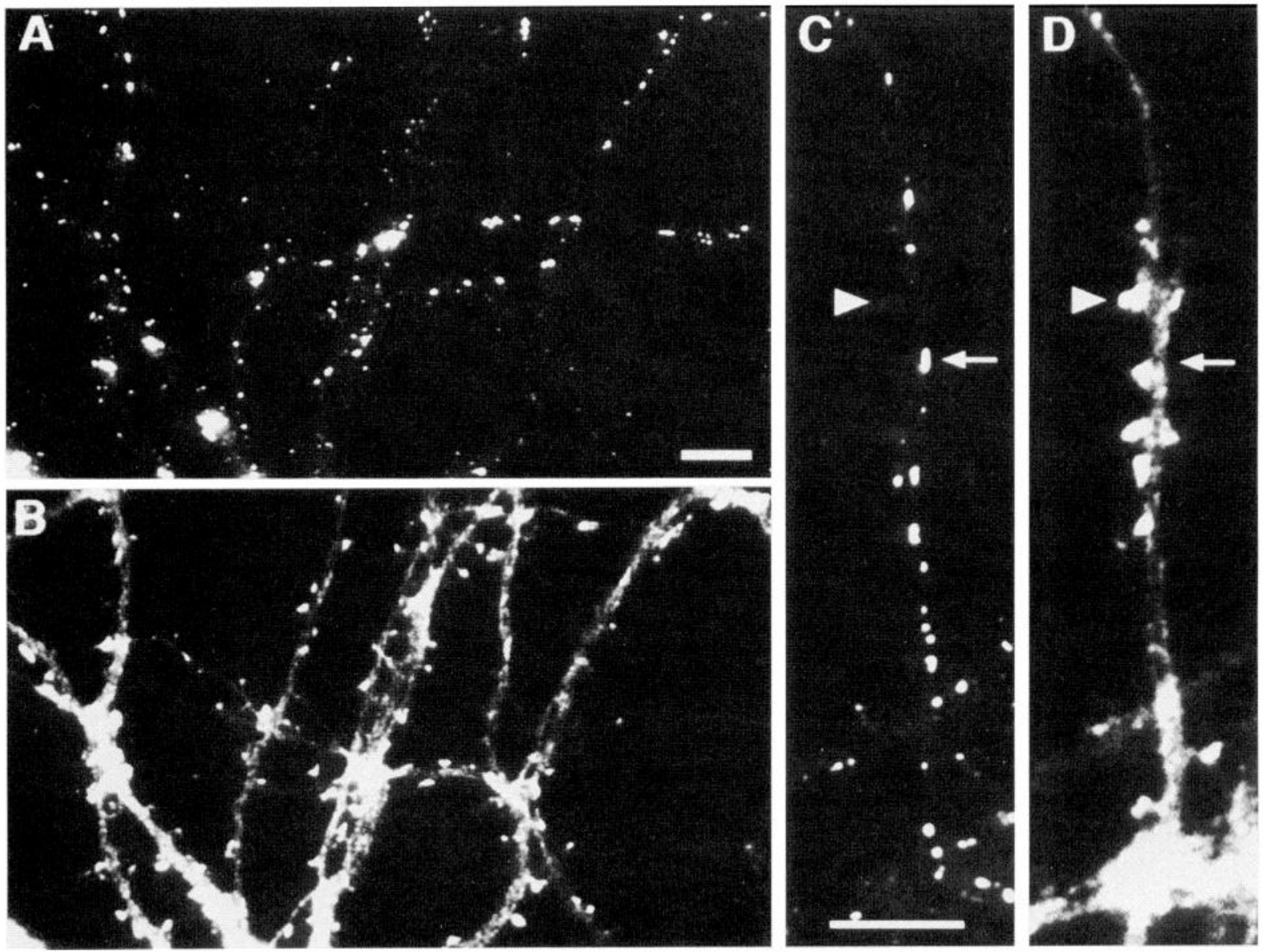

Figure 5. Absence of a relationship between gephyrin clusters and GluR1-labeled glutamate synapses. Hippocampal neurons after 3 weeks in culture were immunolabeled for gephyrin $(A, C)$ and the glutamate receptor subunit GluR1 $(B, D)$. Large gephyrin clusters $($ arrow) did not colocalize with GluR1 clusters (arrowhead). The large gephyrin clusters were always present on dendritic shafts, whereas GluR1 clusters were predominantly on dendritic spines. A minority of GluR1-labeled spines contained small clusters of gephyrin, but the majority of GluR1-labeled synapses contained no detectable gephyrin and the majority of small gephyrin clusters did not colocalize with GluR1 clusters. Scale bars (shown in $A$ and $C$ ): $10 \mu \mathrm{m}$.

centrated in terminals and thus is a more specific marker for GABAergic boutons. Double-labeling with gephyrin and GAD confirmed that sites of large gephyrin clusters are indeed GABAergic synapses (Fig. 8). On most cells, there was a nearly one-to-one correspondence between large gephyrin clusters and GAD-labeled boutons. On some cells, the large gephyrin clusters seemed to be continuous structures, whereas on other cells (e.g., Fig. 7), the "large gephyrin clusters" were actually composed of groups of closely spaced small clusters. Because there are relatively few GABAergic neurons in these cultures, the density of GABAergic innervation varies. Some dendrites received no GABAergic input; these dendrites exhibited small gephyrin clusters but no large gephyrin clusters (Fig. 9A,B). Dendrites that received GABAergic input and had large gephyrin clusters tended to have fewer small gephyrin clusters (Fig. $9 C, D$ ), although this was not always the case (Fig. 9E,F).

The characteristics of the gephyrin clusters, and the nature of their association with GABAergic innervation, were quantified from digital images of cells double-labeled for gephyrin and GABA (Table 1). Each region of gephyrin immunofluorescence above a user-defined threshold intensity was considered a cluster, and its size and intensity were determined. Images were then examined in the second fluorescent channel to determine whether the gephyrin cluster occurred at a site of GABA labeling or at a site that lacked GABA innervation. Pyramidal cells with variable extents of GABAergic innervation were studied, and depending on the cell, anywhere between $4 \%$ and $72 \%$ of the gephyrin clusters occurred at sites of GABA innervation. The gephyrin clusters associated with GABAergic fibers were on average fourfold larger than those elsewhere along the dendrites $\left(0.86 \mu \mathrm{m}^{2} \mathrm{vs}\right.$ $\left.0.23 \mu \mathrm{m}^{2}, p<0.001\right)$. The clusters not associated with GABA innervation were typically circular, with a diameter of $0.5-0.6 \mu \mathrm{m}$, whereas the clusters associated with GABA innervation were typically more elongated in shape and sometimes seemed to be composed of 4-10 of the small clusters. The fluorescence intensity of GABA-associated clusters was also slightly but significantly greater $(p<0.001)$.

Finally, it is important to note that there was considerable variability among cells in the size and staining intensity of gephyrin clusters. Large clusters were not present in all cells, including some cells in mature cultures that received significant GABAergic innervation. When large clusters were present, their number and distribution generally paralleled the extent and pattern of GABA innervation. As is the case for postsynaptic receptor clustering, which also varies from cell to cell and to a greater degree from one culture preparation to another, the extent to which large clusters of gephyrin formed seemed to be a characteristic of both the postsynaptic cell and the extent of innervation. 

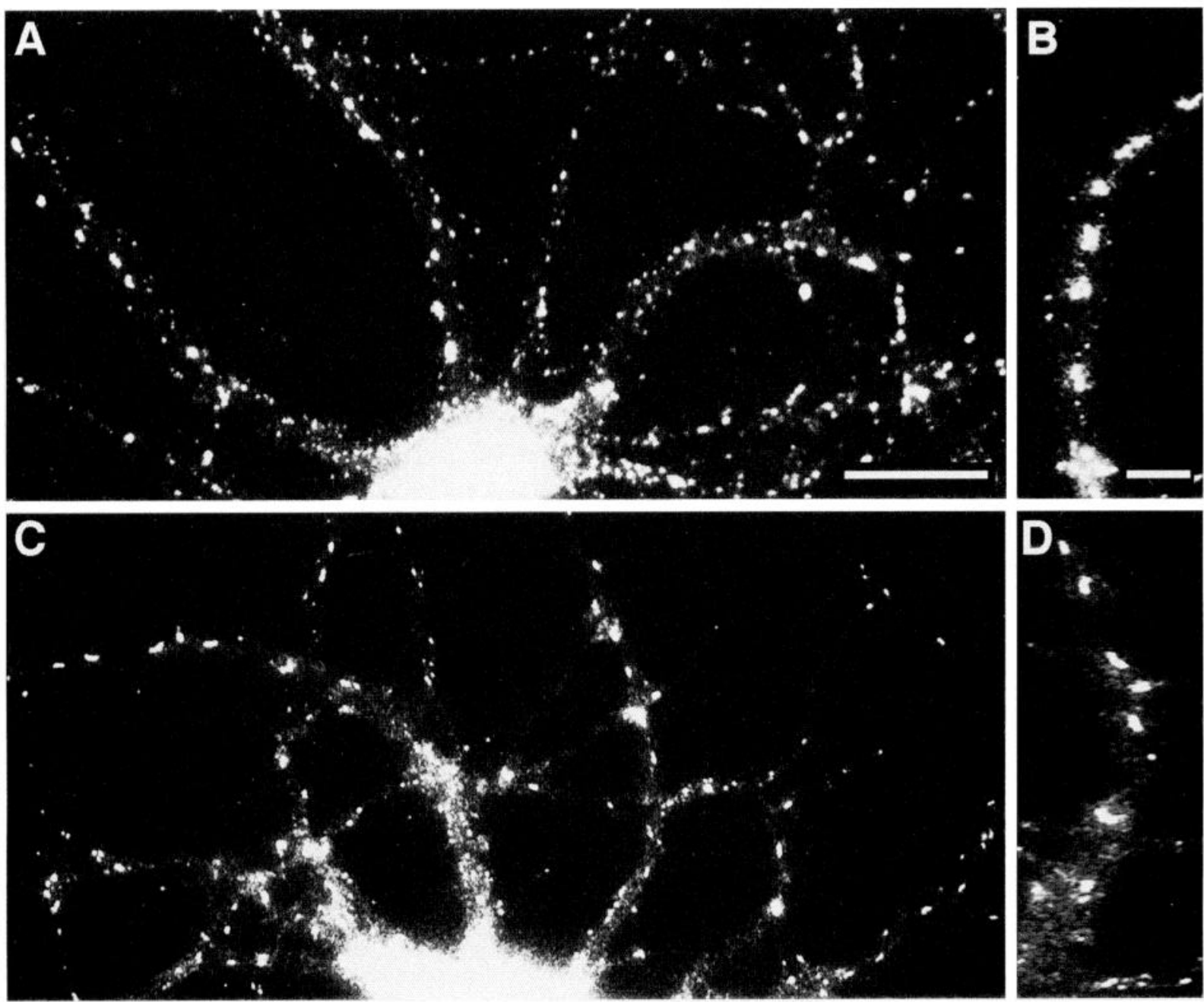

Figure 6. Similar distribution patterns of gephyrin and the $\mathrm{GABA}_{\mathrm{A}}$ receptor $\beta 2 / 3$ subunits on different pyramidal cells. Hippocampal neurons after 3 weeks in culture were labeled for either gephyrin $(A, B)$ or $\mathrm{GABA}_{\mathrm{A}}$ receptor $\beta 2 / 3$ subunits $(C, D)$. This was not a double-label experiment, because these two antibodies are from the same species. The overall distribution patterns were similar for both proteins in that large clusters of both proteins were of roughly the same size, were elongated in shape, and were present on dendritic shafts but not on spines. There were additional small clusters of gephyrin that did not have a GABA receptor counterpart. Although it may not be apparent here, the diffuse dendritic staining was generally higher for the GABA receptor subunits than for gephyrin. Scale bars: $A, C, 20 \mu \mathrm{m} ; B, D, 10 \mu \mathrm{m}$.

\section{DISCUSSION}

Our results reveal several novel features about the localization of gephyrin in hippocampal neurons, a class of cells that receive no glycinergic synapses. First, gephyrin immunoreactivity in hippocampal neurons always takes the form of clusters. There are two types of clusters, which differ in size and in subcellular localization. Larger clusters of gephyrin are localized selectively to GABAergic but not glutamatergic synapses. Smaller clusters of gephyrin are not restricted to synaptic sites or even to dendrites. They arise early in development, well before synaptogenesis, and initially are distributed preferentially to axons. As the cells mature, axonal staining declines and dendritic staining becomes more prominent. On the basis of this distribution pattern, gephyrin is likely to have multiple functions in neurons, perhaps mediated by different forms of the protein.

\section{Selective clustering of gephyrin at GABAergic synapses}

Previous studies, based on immunoelectron microscopy or on immunofluorescence staining of tissue sections, have shown that gephyrin is present at GABAergic synapses in the retina and spinal cord (Cabot et al., 1995; Sassoè-Pognetto et al., 1995). Here we have demonstrated a close correspondence between large gephyrin clusters and GABAergic synapses in hippocampal cultures, a system that lacks glycinergic transmission. Furthermore, using a low density culture system, we presented a clear picture of gephyrin distribution within entire individual neurons and demonstrated a specific association with sites of GABAergic but not glutamatergic innervation.

Definitive evidence of whether the large synaptic clusters of gephyrin in hippocampal neurons are pre- or postsynaptic will require immunoelectron microscopy, but three lines of reasoning support a postsynaptic localization. First, all previous studies have observed that the gephyrin present at synapses is postsynaptic. Second, at 3 weeks in culture, when we observed the striking clusters at GABAergic synapses, gephyrin was predominantly dendritic. A small minority of isolated axons were immunoreactive, but these generally did not correspond to GABAergic axons. Finally, the large synaptic gephyrin clusters formed much later in development than synaptic vesicle clusters did, but with roughly the same time course as postsynaptic receptor clusters (Fletcher et 

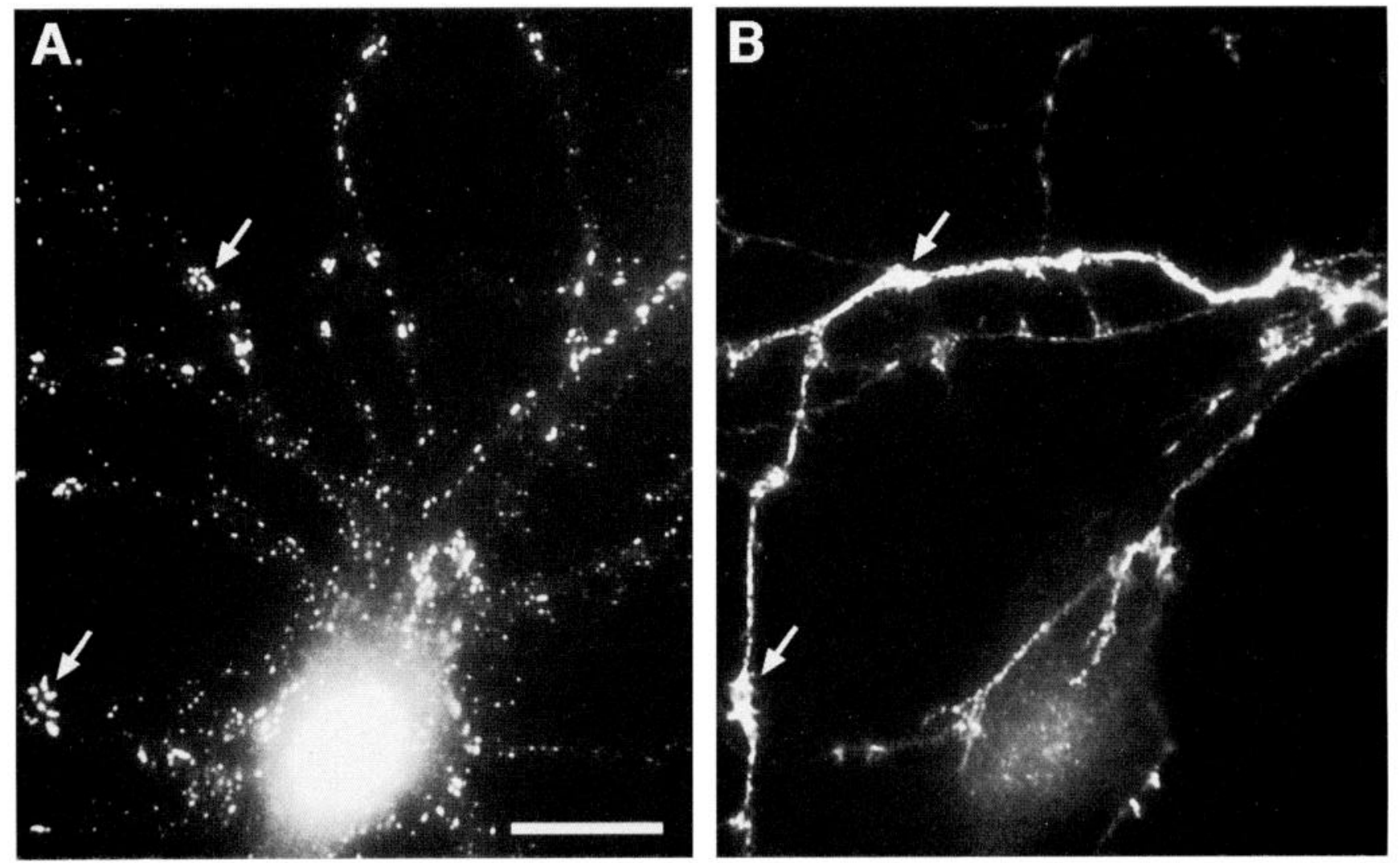

Figure 7. Selective clustering of gephyrin at sites of contact between dendrites and GABAergic axons. Hippocampal neurons after 3 weeks in culture were labeled for gephyrin $(A)$ and GABA $(B)$. Gephyrin was detected in small clusters throughout the soma and dendrites and in larger clusters, or closely spaced groups of small brighter clusters, at points of contact with GABA axons (arrows). The cell shown is a pyramidal cell; the GABAergic axon originated from a nearby interneuron. Scale bar (shown in $A$ ): $10 \mu \mathrm{m}$.

al., 1991, 1994; Craig et al., 1993, 1994). The formation of large gephyrin clusters also exhibited a high degree of variability from cell to cell and from one culture preparation to the next. Postsynaptic receptor clustering in cultured neurons is also quite variable, whereas the formation of synaptic vesicle clusters is consistent among different culture preparations.

The obvious inference from these results is that gephyrin may function to anchor $\mathrm{GABA}_{\mathrm{A}}$ receptors at postsynaptic sites in hippocampal neurons, just as it anchors glycine receptors in spinal cord neurons. Consistent with this possibility, GABA and glycine receptors share significant sequence homology, but exhibit no homology with members of the glutamate receptor family. On coexpression of gephyrin and $\mathrm{GABA}_{\mathrm{A}}$ receptor subunits in fibroblasts, $\beta 3$ but not other subunits showed a partial colocalization with gephyrin in intracellular aggregates (Kirsch et al., 1995). Although Meyer et al. (1995) found that recombinant gephyrin interacts directly with the glycine receptor $\beta$ subunit, they were unable to detect interaction with the most closely related $\mathrm{GABA}_{\mathrm{A}}$ receptor subunits, including $\beta 3$, by direct biochemical methods. It may be that some $\mathrm{GABA}_{\mathrm{A}}$ receptor subunits such as $\beta 3$ interact with a particular post-translational modification of gephyrin.

\section{Nonsynaptic clusters of gephyrin}

Two findings in this study were completely unexpected. In light of previous immunoelectron microscopic studies of gephyrin localization, which demonstrated consistently that gephyrin was restricted to a specific subset of postsynaptic sites (Triller et al., 1985, 1987; Mitchell et al., 1993; Cabot et al., 1995), we were surprised to find that gephyrin was not restricted to dendrites but was also present in axons; in fact, early in development gephyrin is concentrated preferentially in axons. Equally surprising, gephyrin was associated with clusters of two distinct sizes, and the smaller clusters bore no relationship to synapses, even in mature cultures that were densely innervated. At present we can only speculate about the significance of these small clusters, which were found in both axons and dendrites. It may be that these are sites where gephyrin is functioning to anchor some other membrane protein to the cytoskeleton, or they may represent intracellular aggregates, perhaps associated with vesicles in transit to the cell surface. At any rate, the presence of widely distributed, nonsynaptic clusters of gephyrin raises the possibility that this protein subserves additional functions in neurons, independent of receptor clustering. This possibility is consistent with the finding that gephyrin is expressed in many cell types besides neurons (Prior et al., 1992).

It is unclear at present how to relate our findings with previous studies of gephyrin localization in spinal cord cultures. In 10-d-old spinal cord cultures, when neurons are already innervated, only one size class of gephyrin clusters has been described $\left(0.28 \mu \mathrm{m}^{2}\right.$; Kirsch and Betz, 1995). These correspond in size to the smaller clusters observed in hippocampal cultures, but unlike those in hippocampal neurons, they are restricted largely to synaptic sites. It is not clear whether this reflects a difference in cell type or whether larger clusters also appear at later times in spinal cord cultures. It is also possible that the size differences simply reflect a difference in the imaging techniques used to make these measurements. 

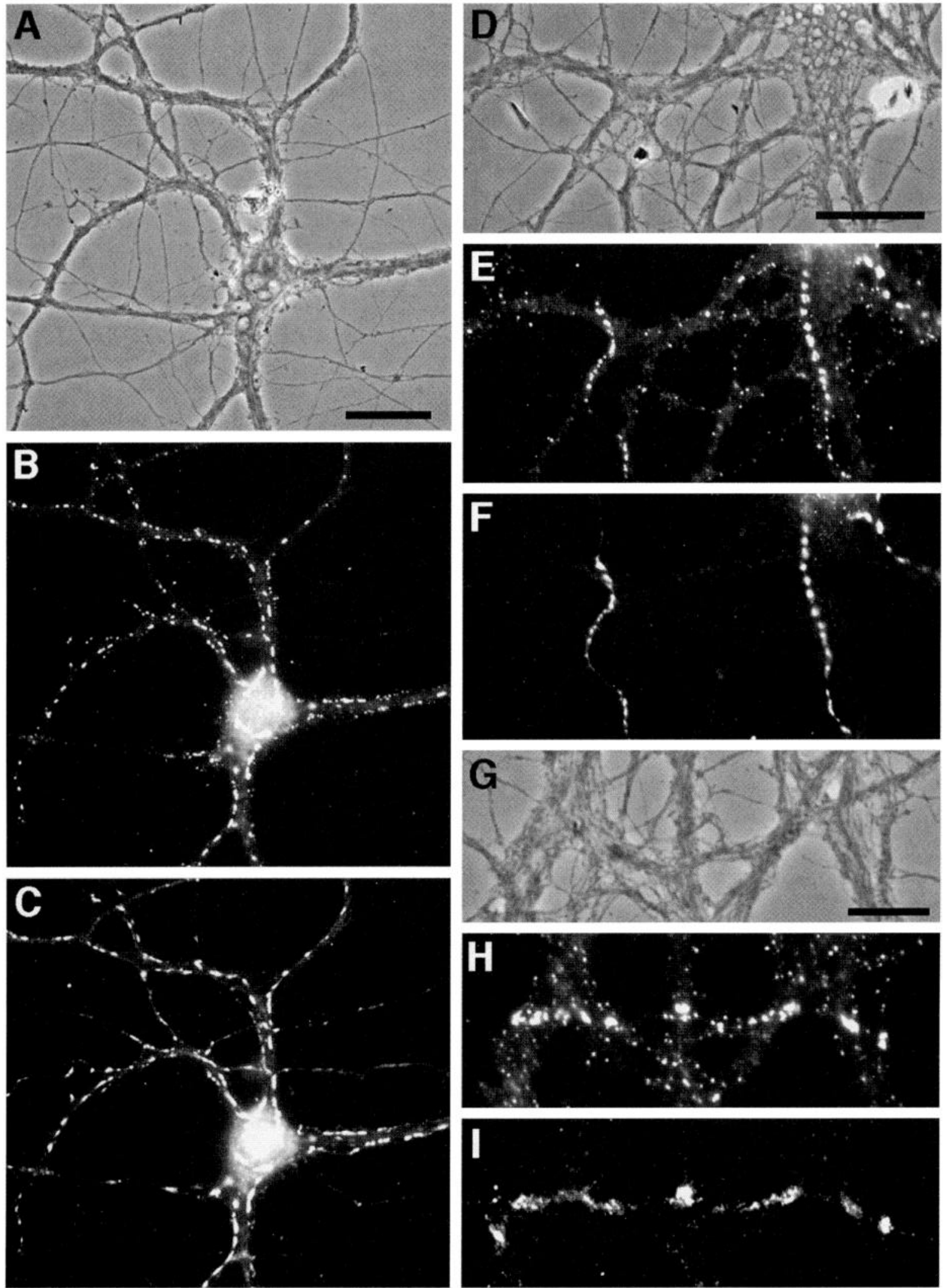

Figure 8. Selective clustering of gephyrin at GABAergic synapses. Hippocampal neurons after 3-4 weeks in culture were immunolabeled for gephyrin $(B, E, H)$ and GAD, a marker of GABAergic terminals $(C, F, I)$. There was a largely one-to-one correspondence between large gephyrin clusters and GAD-labeled boutons. Presynaptic versus postsynaptic sites were not distinguishable at this level of resolution, and so the apparent colocalization is consistent with apposition of presynaptic GAD and presumably postsynaptic gephyrin. Smaller gephyrin clusters, most prominent in $H$, did not colocalize with $\mathrm{GAD}$. The phase-contrast micrographs $(A, D, G)$ indicate the presence of many unlabeled axons and regions of dendrites. The cells shown here are all pyramidal cells; the GABAergic axons originated from nearby interneurons. Scale bars: $A-F, 20 \mu \mathrm{m} ; G-I, 10 \mu \mathrm{m}$. 

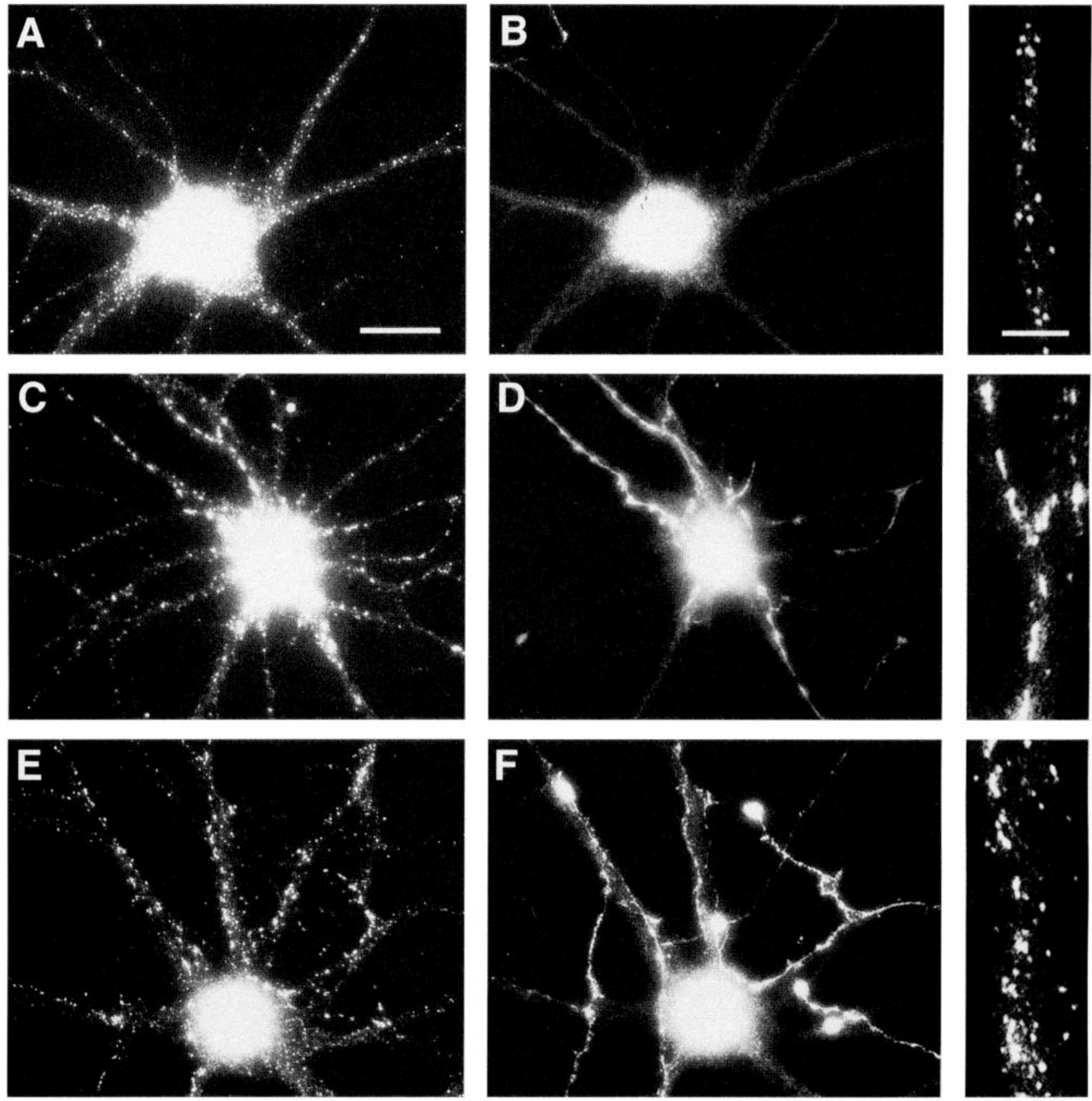

Figure 9. Correlation of gephyrin cluster size with GABAergic innervation. Hippocampal neurons after $24 \mathrm{~d}$ in culture were labeled for gephyrin ( $A$, $C$, $E)$ and $\operatorname{GABA}(B, D, F)$. Panels on the right show an enlargement of gephyrin staining in one of the dendrites. Gephyrin cluster size was uniformly small in dendrites lacking GABAergic innervation $(A, B)$. Innervated dendrites exhibited either very large clusters $(C, D)$, or more commonly, both large and small clusters $(E, F)$. The cells shown here are all pyramidal cells from a single coverslip; the GABA-staining in the cell bodies is background because of the greater thickness of the cell bodies. Scale bars: $A-F, 20 \mu \mathrm{m}$; right panels, $5 \mu \mathrm{m}$.

Most proteins that exhibit a polarized distribution in hippocampal neurons become polarized relatively early in development (for review, see Craig and Banker, 1994). Most axonal proteins become segregated to the axon as soon as it develops (at 1-2 d in culture), and most dendritic proteins become segregated as dendrites begin to mature (at 4-6 d in culture). Thus, the gradual shift in localization of gephyrin from axons to dendrites between 1 and 3 weeks in culture is unusual. This change in localization could be attributable to a developmentally regulated posttranslational modification of gephyrin, to the association of gephy- rin with other proteins expressed at different stages of development, or to developmental changes in the expression of alternatively spliced forms of gephyrin. Gephyrin transcripts can exist in different isoforms including or lacking four cassettes, C1-C4 (Prior et al., 1992). Expression of transcripts containing the C3 cassette decreases during embryonic development (Kirsch et al., 1993a). Thus it is possible that the C3 cassette, consisting of 36 amino acids, directs gephyrin to axons, whereas forms lacking C3 may be dendritic. Isoform-specific antibodies will be required to test this hypothesis. 
Table 1. Difference in gephyrin cluster size and relative fluorescence intensity at GABA synapses versus elsewhere on the neuron

\begin{tabular}{|c|c|c|c|c|c|c|c|c|}
\hline \multirow[b]{2}{*}{ Cell } & \multicolumn{2}{|l|}{ Area $\left(\mu \mathrm{m}^{2}\right)$} & \multirow[b]{2}{*}{$p$} & \multicolumn{2}{|l|}{ Intensity } & \multirow[b]{2}{*}{$p$} & \multicolumn{2}{|l|}{$\underline{n}$} \\
\hline & GABA+ & GABA- & & $\mathrm{GABA}+$ & $\mathrm{GABA}-$ & & $\mathrm{GABA}+$ & GABA- \\
\hline 1 & $104 \pm 117$ & $016 \pm 014$ & $<00001$ & $069 \pm 015$ & $054 \pm 007$ & $<00001$ & 73 & 139 \\
\hline 2 & $742 \pm 714$ & $024 \pm 031$ & 006 & $093 \pm 006$ & $069 \pm 006$ & 00006 & 6 & 130 \\
\hline 3 & $057 \pm 096$ & $025 \pm 030$ & 00005 & $067 \pm 010$ & $065 \pm 009$ & 013 & 143 & 56 \\
\hline 4 & $056 \pm 093$ & $025 \pm 037$ & $<00001$ & $074 \pm 009$ & $072 \pm 006$ & 004 & 161 & 102 \\
\hline 5 & $133 \pm 202$ & $030 \pm 049$ & 001 & $083 \pm 011$ & $071 \pm 008$ & $<00001$ & 29 & 127 \\
\hline 6 & $079 \pm 110$ & $015 \pm 012$ & $<00001$ & $076 \pm 011$ & $065 \pm 006$ & $<00001$ & 55 & 44 \\
\hline 7 & $122 \pm 186$ & $021 \pm 022$ & $<00001$ & $068 \pm 007$ & $061 \pm 007$ & $<00001$ & 71 & 77 \\
\hline Averages & $086 \pm 124$ & $023 \pm 029$ & $<00001$ & $072 \pm 010$ & $065 \pm 007$ & $<00001$ & 538 & 675 \\
\hline
\end{tabular}

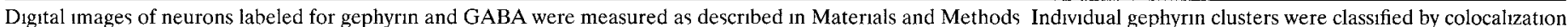

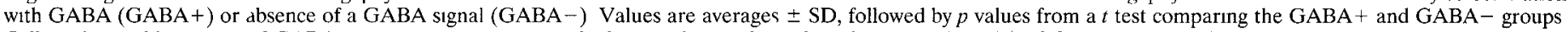
Cells with variable extents of GABAergic innervation were studied, as is obvious from the relative numbers $(n)$ of $\mathrm{GABA}+$ versus $\mathrm{GABA}-\mathrm{clusters}$ per cell

\section{Implications for receptor clustering}

It is clear from our results that gephyrin and $\mathrm{GABA}_{\mathrm{A}}$ receptors are not always associated At 1 week in culture, when gephyrm is punctate and axonal, the $\mathrm{GABA}_{\mathrm{A}}$ receptor $\beta 2 / 3$ subunits are diffusely distributed in the plasma membrane and polarized to dendrites Even in older neurons, $\mathrm{GABA}_{\mathrm{A}}$ receptors and gephyrın are colocalized at GABAergic synaptic sites, but $\mathrm{GABA}_{\mathrm{A}}$ receptors are not associated with the smaller, nonsynaptic gephyrin clusters These results suggest that only a specific form of gephyrin, either a splice variant or a post-translationally modified form, can interact with $\mathrm{GABA}_{\mathrm{A}}$ receptors We have argued previously that there must be some local control over receptor clustering to account for its specificity that GABA receptors cluster opposite GABAergic but not glutamatergic termınals (Craig et al, 1994) Local control could involve local modification of gephyrin, of GABA receptors, or of another associated protem A related issue pertains specifically to cells that receive separate GABAergic and glycinergic input Are GABA and glycine receptors associated selectively with the appropriate postsynaptic sites in such cells? If so, and if gephyrin anchors both receptor types, this would imply that different splice variants or post-translationally modified forms differ in the specificity of their interactions with receptors Even in developing hippocampal neurons, although there is no evidence for glycinergic synaptic transmission, some glycine receptor subunits may be expressed, including $\alpha 2$ and the gephyrın-binding $\beta$ subunit, rassing the question of whether and how they may be segregated from GABA receptors and whether, for example, they may be associated with the small nonsynaptic gephyrin clusters Additional studies aimed at understanding the functions of gephyrin in hippocampal neurons will have to take into account both glycine and GABA receptors as well as different forms of gephyrin

Our results suggest that gephyrin is not involved in glutamate receptor clustering The hypothesis proposed by Kırsch and Betz (1995) that gephyrm forms a bridge between microtubules and receptors is reconciled more easily with a role in clustering receptors on dendritic shafts than on spines, which lack microtubules Even in shafts, the distance between the plasma membrane and microtubules is rather large to be bridged by a single molecule, but recent evidence that gephyrin can form filaments in fibroblasts (Kursch et al , 1995) may fill this gap Thus there seem to be at least three families of molecules that are involved in anchoring transmitter receptors the $43 \mathrm{~K}$ protein for acetylcholine receptors, gephyrin for glycine and likely GABA receptors, and an additıonal family, possibly including PSD-95 (Kornau et al, 1995), for glutamate receptors

\section{REFERENCES}

Apel ED, Roberds SL, Campbell KP, Merlıe JP (1995) Rapsyn may function as a link between the acetylcholine receptor and the agrınbinding dystrophin-associated glycoprotem complex Neuron 15 $115-126$

Banker GA, Cowan WM (1977) Rdt hippocampal neurons in dispersed cell culture Bran Res 126 397-425

Bartlett WP, Banker GA (1984) An electron microscopıc study of the development of axons and dendrites by hippocampal neurons in culture II Synaptic relationshıps J Neurosci 4 1954-1965

Bekkers JM, Stevens CF (1991) Excitatory and inhibitory autaptic currents in isolated hippocampal neurons mantaned in cell culture Proc Natl Acad Sc1 USA 88 7834-7838

Benson DL, Watkıns FH, Steward O, Banker G (1994) Characterization of GABAergic neurons in hippocampal cell cultures J Neurocytol $23279-295$

Blackstone CD, Moss SJ, Martın LJ, Levey AI, Price DL, Huganır RL (1992) Biochemical characterization and localization of a non- $N$ methyl-D-aspartate glutamate receptor in rat brain $\mathrm{J}$ Neurochem $581118-1126$

Bolhalter S, Mohler H, Fritschy J-M (1994) Inhibitory neurotransmission in rat spinal cord co-localization of glycine- and $\mathrm{GABA}_{\mathrm{A}}$-receptors at $\mathrm{G} \wedge \mathrm{B} \wedge$ ergic synaptic contacts demonstrated by triple immunofluorescence staining Brain Res 642 59-69

Bottenstein JE, Sato GE (1979) Growth of a rat neuroblastoma cell line in serum-free supplemented medium Proc Natl Acad Scı USA $76514-519$

Cabot JB, Bushnell A, Alessı V, Mendell NR (1995) Postsynaptic gephyrin immunoreactivity exhibits a nearly one-to-one correspondence with gamma-amınobutyric acıd-lıke immunogold-labeled synaptıc inputs to sympathetıc preganglıonıc neurons J Comp Neurol 356 418-432

Chen S, Hillman DE (1993) Colocalization of neurotransmitters in the deep cerebellar nucle1 J Neurocytol 22 81-91

Collingridge GL, Gage PW, Robertson B (1984) Inhibitory post-synaptic currents in rat hippocampal CA1 neurones J Physiol (Lond) 356 551-564

Craig AM, Banker G (1994) Neuronal polarity Annu Rev Neurosci $17267-310$

Craig AM, Blackstone CD, Huganır RL, Banker G (1993) The distribution of glutamate receptors in cultured rat hippocampal neurons postsynaptic clustering of AMPA-selective subunits Neuron 10 1055-1068

Craig AM, Blackstone CD, Huganır RL, Banker G (1994) Selectıve clustering of glutamate and $\gamma$-amınobutyric acid receptors opposite termınals releasing the corresponding neurotransmitters Proc Natl Acad Sc1 USA 91 12373-12377

Eshhar N, Petralıa RS, Wınters CA, Nıedzıelskı AS, Wenthold RJ (1993) The segregation and expression of glutamate receptor subunits in cultured hippocampal neurons Neuroscience 57 943-964 
Ewert M, Shivers BD, Lüddens H, Möhler H, Seeburg PH (1990) Subunit selectivity and epitope characterization of mAbs directed against the GABA /benzodiazepine receptor. J Cell Biol 110:2043-2048.

Fallon JR, Hall ZW (1994) Building synapses: agrin and dystroglycan stick together. Trends Neurosci 17:469-473.

Falls DL, Rosen KM, Corfas G, Lane WS, Fischbach GD (1993) ARIA, a protein that stimulates acetylcholine receptor synthesis, is a member of the neu ligand family. Cell 72:801-815.

Fletcher TL, Cameron P, DeCamilli P, Banker G (1991) The distribution of synapsin I and synaptophysin in hippocampal neurons developing in culture. J Neurosci 11:1617-1626.

Fletcher TL, Decamilli P, Banker G (1994) Synaptogenesis in hippocampal cultures: evidence indicating that axons and dendrites become competent to form synapses at different stages of neuronal development. J Neurosci 14:6695-6706.

Froehner SC (1993a) Anchoring glycine receptors. Nature 366:719.

Froehner SC (1993b) Regulation of ion channel distribution at synapses. Annu Rev Neurosci 16:347-368.

Goslin K, Banker G (1991) Rat hippocampal neurons in low density culture. In: Culturing nerve cells (Banker G, Goslin K, eds), pp 251-282. Cambridge, MA: MIT.

Hall ZW, Sanes JR (1993) Synaptic structure and development: the neuromuscular junction. Cell 72/Neuron 10[Suppl]:99-121.

Halpain S, Greengard P (1990) Activation of NMDA receptors induces rapid dephosphorylation of the cytoskeletal protein MAP2. Neuron $5: 237-246$.

Ito S, Cherubini E (1991) Strychnine-sensitive glycine responses of neonatal rat hippocampal neurones. J Physiol (Lond) 440:67-83.

Kaufman DL, Houser CR, Tobin AJ (1991) Two forms of the $\gamma$-aminobutyric acid synthetic enzyme glutamate decarboxylase have distinct intraneuronal distributions and cofactor interactions. $J$ Neurochem 56:720-723.

Kirsch J, Betz H (1993) Widespread expression of gephyrin, a putative glycine receptor-tubulin linker protein, in rat brain. Brain Res 621:301-310

Kirsch J, Betz H (1995) The postsynaptic localization of the glycine receptor-associated protein gephyrin is regulated by the cytoskeleton. J Neurosci 15:4148-4156.

Kirsch J, Kuhse J, Betz H (1995) Targeting of glycine receptor subunits to gephyrin-rich domains in transfected human embryonic kidney cells. Mol Cell Neurosci 6:450-461.

Kirsch J, Langosch D, Prior P, Littauer UZ, Schmitt B, Betz H (1991) The $93 \mathrm{kDa}$ glycine receptor-associated protein binds to tubulin. $\mathrm{J} \mathrm{Biol}$ Chem 266:22242-22245.

Kirsch J, Malosio M-L, Wolters I, Betz H (1993a) Distribution of gephyrin transcripts in the adult and developing rat brain. Eur J Neurosci 5:1109-1117.

Kirsch J, Wolters I, Triller A, Betz H (1993b) Gephyrin antisense oligonucleotides prevent glycine receptor clustering in spinal neurons. Nature 366:745-748.

Koontz MA, Hendrickson LE, Brace ST, Hendrickson AE (1993) Immunocytochemical localization of GABA and glycine in amacrine and displaced amacrine cells of Macaque monkey retina. Vision Res 33:2617-2628.

Kornau H-C, Schenker LT, Kennedy MB, Seeburg PH (1995) Domain interaction between NMDA receptor subunits and the postsynaptic density protein PSD-95. Science 269:1737-1740.

Malosio M-L, Marquèze-Pouey B, Kuhse J, Betz H (1991) Widespread expression of glycine receptor subunit mRNAs in the adult and developing rat brain. EMBO J 10:2401-2409.

McMahan UJ, Horton SE, Werle MJ, Honig LS, Kröger S, Ruegg MA, Escher $\mathrm{G}$ (1992) Agrin isoforms and their role in synaptogenesis. Curr Opin Cell Biol 4:869-874.

Meyer G, Kirsch J, Betz H, Langosch D (1995) Identification of a gephyrin binding motif on the glycine receptor $\beta$ subunit. Neuron 15:563-572.

Mitchell K, Spike RC, Todd AJ (1993) An immunocytochemical study of glycine receptor and GABA in laminae I-III of rat spinal dorsal horn. $\mathrm{J}$ Neurosci 13:2371-2381.

Navone F, Jahn R, DiGioia G, Stukenbrok H, Greengard P, DeCamilli P (1986) Protein p38: an integral membrane protein specific for small synaptic vesicles of neurons and neuroendocrine cells. J Cell Biol 103:2511-2527.

Ottersen OP, Storm-Mathisen J, Somogyi P (1988) Colocalization of glycine-like and GABA-like immunoreactivities in Golgi cell terminals in the rat cerebellum: a postembedding light and electron microscopic study. Brain Res 450:342-353.

Pfeiffer F, Graham D, Betz H (1982) Purification by affinity chromatography of the glycine receptor of rat spinal cord. J Biol Chem 257:9389-9393.

Pfeiffer F, Simler R, Grenningloh G, Betz H (1984) Monoclonal antibodies and peptide mapping reveal structural similarities between the subunits of the glycine receptor of rat spinal cord. Proc Natl Acad Sci USA 81:7224-7227.

Prior P, Schmitt B, Grenningloh G, Pribilla I, Multhaup G, Beyreuther K, Maulet Y, Werner P, Langosch D, Kirsch J, Bctz H (1992) Primary structure and alternative splice variants of gephyrin, a putative glycine receptor-tubulin linker protein. Neuron 8:1161-1170.

Sassoè-Pognetto M, Kirsch J, Grünert U, Greferath U, Fritschy JM, Möhler H, Betz H, Wässle H (1995) Colocalization of gephyrin and $\mathrm{GABA}_{\mathrm{A}}$-receptor subunits in the rat retina. J Comp Neurol 357:1-14.

Segal M, Barker JL (1984) Rat hippocampal neurons in culture: voltageclamp analysis of inhibitory synaptic connections. J Neurophysiol 52:469-487.

Todd AJ, Sullivan AC (1990) Light microscope study of the coexistence of GABA-like and glycine-like immunoreactivities in the spinal cord of the rat. J Comp Neurol 296:496-505.

Triller A, Cluzeaud F, Korn H (1987) Gamma-aminobutyric acidcontaining terminals can be apposed to glycine receptors at central synapses. J Cell Biol 104:947-956.

Triller A, Cluzeaud F, Pfeiffer F, Betz H (1985) Distribution of glycine receptors at central synapses: an immunoelectron microscopy study. J Cell Biol 101:683-688. 